\title{
Létezik-e német hegemónia az Európai Parlamentben?
}

\section{Is There German Hegemony in the European Parliament?}

Baranyi Márton

https://doi.org/10.47707/Kulugvi_Szemle.2021.4.1

Összefoglaló: Az Európai Unión belüli német hegemónia vizsgálata és értékelése egy örökzöld, ám egyúttal vitatott kutatási témának számít. Egyrészről nem tisztázott, hogy mely kritériumok teljesülése esetén számít egy domináns hatalom hegemónnak, másrészről Németországnak az Európában betöltött szerepe kapcsán sem világos, hogy a múltjából fakadó adósságából eredően milyen mértékben hajlandó az európai vezető szerepnek eleget tenni. A jelen tanulmányban a német hegemóniával kapcsolatos vizsgálat középpontjában az Európai Parlament áll, de meg kell jegyezni, hogy az intézmény nem tekinthető az EU-n belüli német hegemónia elsődleges megnyilvánulási terepének. Az elemzés a 2014-2019-es parlamenti ciklusra fókuszál, s az EP-képviselók törvénykezési aktivitásán keresztül világítja meg a német hegemónia mérté két, és különböző mutatók értékelésével arra a következtetésre jut, hogy bár az adott időszakban a vezető pozíciók tekintetében túlsúlyban voltak a német képviselők, a parlamenti aktivitás már korántsem német dominanciát tükröz.

Kulcsszavak: Németország, Európai Parlament, hegemónia, jelentéstevő, jogalkotási aktivitás

Abstract: German hegemony within the European Union can be considered as both a recurrent and a much contested research topic. First, it is not clear which criteria have to be fulfilled in order to become a hegemon; second, Germany's degree of willingness to take on the leadership role within the European Union is also unclear. The current study analyses German hegemony within the European Parliament by focusing on the 2014-2019 legislative period, and by assessing various measures and criteria related to the legislative activity and leading parliamentary posilions of German MEPs. The study finds that, despite German MEPs taking high-ranking positions in the analysed legislative period, their activity is by far not dominant, and therefore the study concludes that German hegemony is not mirrored in the EP. 
Keywords: Germany, European Parliament, hegemony, rapporleur, legislative activity

\section{Bevezetés}

Európai Németország vagy német Európa? A kérdés nem új keletű: a szakirodalomban csak németkérdésként azonosított tétel azt az Európában évszázadok óta létező hatalmi dilemmát taglalja, miszerint Németország önmagában túl erős ahhoz, hogy betagozódjon az európai országok sorába, ugyanakkor túlságosan is gyenge, hogy huzamosabb ideig Európa uralkodó hatalma legyen. A németkérdés 21. századi reneszánszához a német újraegyesülés és az Európai Unió 2004-es bővítése következtében megváltozott és eltolódott európai hatalmi viszonyok adták a kezdőlökést, illetve az eurózóna 2008-as válságának a kezelése kapesán lett nyilvánvaló, hogy a német újraegyesítés óta eltelt időszakban, valamint a Gazdasági és Monetáris Unió létrejöttével Németország Európa vezető gazdasági hatalmává vált.

Hegemón-e Németország? A válasz nem egyértelmű - annak ellenére sem, hogy számos kutatás fókuszál az országnak a különböző politikai és gazdasági szakterületeken, több uniós intézmény és időszak tekintetében vállalt vezető szerepére. A jelen tanulmány alapját adó komplex kutatás (Baranyi, 2021) egyik fő következtetése, hogy a hegemónia tudományos igényű megállapításához, vagyis ahhoz, hogy a közvetett átfogó kutatások eredményeként körbeírható legyen a hegemónia egésze mint jelenség, a lehető legtöbb és legalaposabb vizs gálat elvégzése szüikséges. A hivatkozott doktori disszertáció a német hegemónia kérdését öt különböző szemszögből megközelítve törekszik arra, hogy a vizsgálat minél átfogóbb legyen. Az öt terület a következő:

- Németország gazdasági hegemóniája Európában,

- német térnyerés az uniós intézményekben,

- az ország szerepe az uniós tagállamok szempontjából,

- Németország befolyása az uniós döntés-előkészítésre,

- az ország súlya az Európai Parlamentben. 


\section{Külïgyi Szemle}

A jelen tanulmány ez utóbbi dimenziót bontja ki részletesebben. Az eddig leírtakból adódik is az első feltételezés: Németország európai uniós hegemóniája szükségszerűen együtt jár az EU intézményrendszerén belüli dominanciájával is. Ebből következik, hogy amennyiben feltételezzük, hogy Németország az EU-n belül hegemóniára tett szert, akkor a német hatalomnak az Európai Parlament mindennapos múködése kapcsán is tetten érhetőnek kell lennie. Másként megfogalmazva: német hegemónia esetén elvileg az ország európai parlamenti képviselői számítanak a legbefolyásosabbaknak és legaktívabbaknak a legnagyobb demokratikus legitimitással bíró (azaz az egyetlen köz vetlenül választott) uniós intézményben. E cikk célja, hogy a rendel kezésre álló adatsorok elemzésével és különböző mérőszámok megalkotásával a fenti hipotézist körbejárja, azaz kiderüljön, hogy valóban a német képviselők tekinthetők-e a legaktívabbaknak (pl. közülüik vállalták-e a jelentéstevői szerepkört a legnagyobb arányban), illetve ők rendelkeztek-e a legszorosabb összeköttetési hálóval a 2014-2019-es törvénykezési ciklusban.

Fontos hangsúlyozni, hogy a tanulmány unortodox megközelítést alkalmaz: egy olyan uniós intézmény került az elemzés középpontjába, amely a hagyományos szemlélet szerint nem számít a tagállami érdekérvényesítés elsődleges terepének. Az európai integráció mindennapi múködésével kapcsolatban közkeletủ állítás ugyanis, hogy az intézményrendszeren belüli szerepek elosztását már a kezdet kezdetén tisztázták. Ennek megfelelően - az EU-val foglalkozó elméleti megközelítés szerint - az Európai Bizottság az uniós érdekek megjelenítője, az Európai Unió Tanácsa a tagállami érdekek képviseletét látja el, míg az egyedüli közvetlenül megválasztott testület, az Európai Parlament az európai állampolgárok érdekeit artikulálja. E meghatározás értelmében tehát a tagállamok egyedi érdekei nem jelennek meg az Európai Parlament tevékenységében, ugyanakkor mégis feltételezhető, hogy amennyiben egyikük hegemón hatalommal bír az Európai Unión belüil, úgy az az összes intézményen belül érvényesüil, így - az adott tagország képviselőin keresztül - az elsődlegesen és hivatalosan az állampolgári érdekeket megjelenítő EP-ben is. Az ottani 
szavazási adatok historikus felkutatása és elemzése egy elméleti le hetőséget nyúijt arra, hogy kiderüljön, mennyire hatja át a tagállami érdekképviselet az Európai Parlamentet.

A tanulmány szerkezete a következő: először egy rövid szakirodalmi áttekintés olvasható a németkérdés aktualitásáról, továbbá az Európai Parlamentnek az uniós intézményrendszerben tapasztalható, fokozatosan növekvő szerepérôl. Ezt a módszertant ismertető rész követi, amelyből az is kiderüil, hogy a jelen írás az EP nyolcadik törvénykezési ciklusára (2014-2019) leszúkítve törekszik a küiönböző mutatószámok meghatározására és rajtuk keresztuil a rangsorok felállítására. Ezt követően bemutatom a mutatószámok és a rangsorok alapján született eredményeket, s következtetéseket vonok le az Európai Parlamenten belüli német hegemóniára vonatkozóan (küiön hangsúlyozva a jelen tanulmány korlátait).

\section{Az újkori német hegemónia kérdésköre és az Európai Parlament szerepének folyamatos felértékelődése}

Bár a német hegemónia témaköre könyvtárnyi szakirodalmat tölt meg, ugyanakkor - ahogy korábban már utaltam rá - a szerzőknek a mai napig nem sikerült konszenzusra jutniuk abban a kérdésben, hogy Németország hegemónnak tekinthető-e, alkalmazható-e esetében a hegemón stabilitás elmélete, illetve amennyiben az országot hegemónnak fogadjuk el, az teljes mértékben érvényes-e rá.

A nemzetközi kapcsolatok elméleti keretrendszerén belül kiemelt helyet elfoglaló hegemón stabilitás elmélete - dióhéjban és nagyon leegyszerűsítve - azt a nézetet képviseli, hogy az általában instabil nemzetközi rendszer abban az esetben válhat némileg stabillá, ha egy szereplő (állam) a többiek fölé magasodva vezető (hegemón) szerepet vállal. A hegemón aktor a vezető szereppel felelősséget is vállal: biztosítja a nemzetközi rendszer stabilitását azáltal, hogy viseli a fenntar tásával kapcsolatos költségeket. Felmerül a kérdés ugyanakkor, hogy milyen kritériumoknak kell teljesülniük ahhoz, hogy egy domináns 


\section{Külïgyi Szemle}

hatalom hegemónná váljon. Amennyiben a Robert Keohane (1984) ál tal leírt feltételeket vesszüik alapul (nyersanyagok, illetve piacok feletti kontroll, a tőke ellenőrzése, a magas hozzáadott értéket képviselő ter mékek versenyelőnye, továbbá katonai erőfölény), akkor látható, hogy Németország jelenleg nem felel meg azoknak. Az ország valóban az EU gazdasági motorjának számít, hiszen globálisan is az egyik legerő sebb gazdaság és exporthatalom - Európa legnagyobb nemzetgazda sága, a nominális GDP tekintetében globálisan a negyedik helyen áll, és a világ harmadik legjelentősebb exportőre -, továbbá jól teljesít a piaci és a tőkekontroll szempontjából, és versenyelőnyt élvez a magas hozzáadott értéket képviselő termékek terén is. Ugyanakkor a katonai hatalom tekintetében már elenyésző a súlya, és nyersanyagokból is hagyományosan importra szorul. Beverly Crawford (2015) szerint mindazonáltal Németország a „hiányosságai” ellenére gazdasági értelemben egyértelműen Európa hegemónja, és ún. beágyazott hege mónként határozható meg, mivel az európai integráció kezdete óta vezető szerepet játszik az intézményépítésben, és aránytalanul nagy terhet vállalt abban.

Wolfgang Proissl (2010) meglátása, hogy Németország a közös valuta létrehozása óta jóindulatú hegemónnak tekinthető, ugyanis az ország hajlandó volt „feláldozni” a német márkát az európai monetáris rendszer kialakítása érdekében. Szerinte egyébiránt a német lépésnek részben az is volt a célja, hogy csökkentse egyes európai partnereknek az újraegyesült Németország hirtelen megnövekedett erejétől való félelmeit. Thomas Pedersen (2002) az országra kooperatív hegemónként tekint: a francia-német tandem EU-n belüli együittmúködésének értékelésekor arra a következtetésre jutott, hogy a német hegemónia és a nemzetek feletti együittmúködés kialakulása lényegesen stabilabb nemzetközi rendszert eredményezett, mint amit korábbban a hagyományos kormányközi együttmúködés teremtett. Ezért úgy véli, ez az ún. kooperatív hegemónia lehet a sikeres regionális együttmúködés alapja.

Egy, a német hegemóniával kapcsolatos közismert vélekedés szerint az ország csak az utóbbi időben, főleg az eurózóna válságkezelésének 
az eredményeként vált az Európai Unión beül hegemón hatalommá. E szemlélet alapján Németország kvázi „belesodródott” a hegemón szerepkörbe, pedig a múltjára való tekintettel az egyáltalán nem állt szándékában. Simon Bulmer és William Paterson (2013) azzal érvel, hogy Németország a hatalmát az uniós intézményekbe ágyazottan gyakorolja, és az idők folyamán kooperatív hegemónból „vonakodó hegemónná” vált. Christoph Schönberger (2012) a német hegemóniának az európai integrációban betöltött, megkerülhetetlen szerepét hangsúlyozza. Peter Graf Kielmansegg (2017) elismeri a német gazdasági fölény által létrejött hegemóniát, ugyanakkor az eurózóna válságkezelése szempontjából más intézményi szereplők (Európai Központi Bank, Nemzetközi Valutalap) jelentőségét hangsúlyozza.

A témával kapcsolatosan Hans Kundnani (2014) írt egy nagysikerủ könyvet, aki szerint a német hatalom ismét feszültséget és in stabilitást kelt Európában, és arra a következtetésre jutott, hogy a németkérdés a EU-ban immár elsősorban nem biztonsági, hanem geoökonómiai problémaként jelentkezik újra. Kundnani meglátása szerint az euróövezet válságkezelése kapcsán Berlin vonakodott felelősséget vállalni, és elutasította az eurókötvények bevezetését, s egyúttal úgy kívánta az Európai Uniót átalakítani, hogy a saját preferenciáit a partnereire kényszerítse. Így a német hatalom paradoxona az, hogy bár az ország a gazdasági stabilizációra törekszik, a saját, szűken meghatározott stabilitási kultúrája terjesztésével destabilizálja a monetáris uniót (lásd pl. a német gazdasági erőfölény érvényesülését az EU perifériáján [Nagy, 2013]). Melanie Morisse-Schilbach (2011) is úgy véli, hogy Németország egykor jóindulatú hegemónként viselkedett, ám az eurózóna válsága miatt megváltozott a viselkedése, és immár egyoldalúan jár el.

A német hegemóniát illető, igen határozott álláspontot képvisel Stefan Kornelius (2010) és Herfried Münkler (2015a) is. Az előbbi az zal érvelt, hogy az euróövezet válsága miatt Németországnak felül kell emelkednie a saját, szúken értelmezett érdekein, és el kell fogadnia az elkerülhetetlen sorsát: felvállalni a hegemón szerepkört Európában. Münkler hasonló húrokat pengetett: szerinte Németországnak viselnie 


\section{Külïgyi Szemle}

kell a hegemóniával kapcsolatos felelősséget és kötelezettségeket, el fogadnia, hogy az akarata ellenére immár az EU központi hatalmává vált. Továbbá hátra kell hagynia az országot korábban jellemző vonakodó magatartást, és eleget kell tennie a hegemóniával együtt járó kötelezettségeinek, a politikai és gazdasági egyensúly megtartása ér dekében ellensúlyoznia kell a periféria centrifugális eróit.

A fentieknek némileg ellentmondanak a téma magyarországi szakértői. Benczes István elfogadja ugyan a vonakodó hegemónia tézisét, de Németországnak az eurózóna válságában betöltött szerepét vizs gálva arra a következtetésre jutott, hogy korántsem egyértelmú, hogy az ország (regionális) hegemónnak tekinthető-e, mivel nem hajlandó bizonyos, a hegemóniával járó feladatoknak és kötelezettségeknek ele get tenni (Benczes, 2017; Benczes, 2018). Hettyey András a magyarnémet bilaterális kapcsolatokon keresztül vette górcső alá a német hegemóniát, és az államközi kapcsolatok elemzésével arra a következ tetésre jutott, hogy Németország csak gazdasági szempontból domi náns, így összességében nem tekinthető hegemónnak a magyar-né met bilaterális viszonyrendszeren belül (Hettyey, 2019).

Nyilvánvaló, hogy az említett tanulmányok nem vették még figye lembe a koronavírus-járvány hatásait és Németországnak a pandémia okozta válság társadalmi-gazdasági hatásainak az enyhítésében ját szott szerepét. Nem készült még továbbá egy olyan komplex tanul mány, amely Berlin hatalmát mindenre kiterjedően elemezné. De, ahogy az a fenti áttekintésből is kitűnik, az biztos, hogy az Európai Parlament - mint uniós intézmény - eddig egyszer sem szerepelt a német hegemóniával kapcsolatos fontosabb írásokban.

Ennek ellenére fontos kitérni az Európai Parlamenttel kapcsolatos diskurzusok rövid ismertetésére is, mivel az intézménynek a különböző szempontok szerinti vizsgálata régóta kedvelt témája az európai integrációval foglalkozó kutatásoknak. Általánosságban megállapítható, hogy míg az Európai Unió dinamikája korántsem egyenletes és egyirányú (lásd a bővítés/mélyítés sok évtizedre visszatekintő dilem máját't), ugyanez nem vonatkozik az Európai Parlament szerepkörének

1 Az EU-bővités dinamikájával és dilemmáival kapcsolatos aktuális nehézségekről lásd részletesebben: Siljak és Nagy, 2018. 
a változására. Az EP befolyása és hatalma - jogalkotó és döntéshozó szerepe - ugyanis az integráció előrehaladtával folyamatosan nőtt, s ennek közvetlen következményeként fokozatosan növekedett az EP képviselők politikai súlya is, így a teljesítményük és az aktivitásuk vizs gálata is egyre relevánsabbá vált. A lisszaboni szerződés eredménye ként - az EP-képviselők hosszú küzdelmének a megkoronázásaként az EP de jure társjogalkotóvá vált, a jelentősége megközelítette az EU Tanácsáét. A szerződés hatályba lépése óta - még ha jogilag nem is a gyakorlatban tovább erósödött az intézmény az ún. Spitzenkandidat rendszer bevezetése következtében (Brack és Costa, 2018), bár az Európai Bizottság elnökének a 2019-es megválasztása látszólag (és ideiglenesen?) mellékvágányra terelte a csúcsjelölti rendszert. Nem véletlen tehát az EP és az ott ülő képviselők tevékenysége, aktivitása, szavazási magatartása iránti fokozott érdeklődés.

Általános problémaként vethető fel az Európai Parlament (és tulajdonképpen a választott intézmények) esetében, hogy nem létezik olyan univerzális indikátor vagy mérőszám, amely a képviselők jellemzésére (politikai teljesítmény, szavazási magatartás stb.) használ ható lenne. Annak hiánya ellenére több olyan módszertan is napvilágot látott már, amelynek a segítségével mérni és értékelni lehet az EP-képviselők aktivitását. E módszertanok általában két adatforráson alapulnak: egyrészt a név szerinti szavazások alapján értékelik a képviselőket (továbbá az együtt- vagy kiszavazási hajlandóságot, illetve a pártcsaládok szavazási koherenciáját [Hix, 2002; Hix, Noury és Roland, 2005; Hix el al., 2006; Hix el al., 2009]), másrészt a jogszabálytervezetekhez kapcsolódó módosító indítványokon és a jelentéstevői szerepeken keresztül méri a súlyukat és befolyásukat (Kovács, 2021). Megemlíthető továbbá a különböző mérőszámok kapcsán az elkészített jelentések száma, a plenáris ülések látogatottsági aránya vagy a szakpolitikai vezetés - azaz a képviselőknek a jogszabályok tartalmát (a szakpolitikai döntéshozatali folyamatban szakértőként és tárgyaló ként való részvétel révén) befolyásoló, valamint a többiek szavazatát irányító képessége - (Wilson és Thomme, 2016). 


\section{Külïgyi Szemle}

Mint említettem, a korábbi tanulmányok már behatóan foglalkoz tak az Európai Parlament (név szerinti) szavazási adatsoraival, ame lyek révén következtetéseket lehet levonni a képviselők preferenciáira és teljesítményére vonatkozóan. Simon Hix küiönböző kutatásai szerint az Európai Parlamentben a képviselők a politikai szándékaikat leginkább a saját európai pártcsaládjukon keresztüil tudják elérni, s ennek következtében - némiképp meglepő módon - az EP-szavazások hátterében elsődlegesen az adott pártcsaládhoz való lojalitás sejlik fel, nem pedig az ugyanazon tagállamból származó többi kép viselőhöz füződő kapcsolat vagy a nemzeti hovatartozás (Hix, 2002; et al., 2005; Hix et al., 2006; Hix et al., 2009). Thorsten Faas hasonló következtetésre jutott, és megerősítette, hogy az EP-pártcsaládokon belüli kohézió erős, továbbá a szavazás leginkább a pártvonalak mentén történik, és kevésbé számít a nemzeti háttér (Faas, 2002).

Ahogy arról ugyancsak szó volt már, a jogszabálytervezetekhez fü zött módosító indítványok számának az elemzése tekinthető az EP képviselők másik fontos vizsgálatának - egyes kutatások a képvise lők jogalkotási sikerességét éppen ezen indítványok alapján értékelik (Fertő és Kovács, 2019). Ugyanakkor más megközelítések is születtek már. Ilyen az EP-szakbizottságoknak és azok vezetőinek a vizsgálata, azaz annak a tanulmányozása, hogy az ott folyó munka mennyire fontos az egész Európai Parlament működése szempontjából (Kaeding és Obholzer, 2012), illetve a szakbizottsági elnöki poszt betöltése milyen kvalitásokat és specializációt igényel, ha egyáltalán szüikség van valamilyenre (Chiru, 2020). Az említettek mellett kiemelkedő helyet foglal el a jelentéstevői szerepkör vizsgálata is: a vonatkozó kutatások szerint az ugyanis a politikai befolyásosság egyfajta mércéjének is tekinthető, ugyanakkor korántsem egyértelmű, hogy a jelentéstevők adott körülmények között milyen hatalmat és befolyást tudnak gyako rolni (Thierse, 2019).

Fontos még említést tenni azokról a tudományos igénnyel bíró törekvésekről, amelyek bizonyos szempontok alapján mérik és rangsorolják az EP-képviselők (politikai) teljesítményét. Az Eulytixnek a hipotézisem alapjául szolgáló 2020-as jelentése a képviselőket az 
aktivitásuk, az összeköttetéseik szorossága, továbbá a heterogenitá suk szerint rangsorolja (Kovács és Kocsis, 2021). A VoteWatch Europe kvantitatív és kvalitatív vizsgálatokat vegyítve állítja fel az EP-képviselők politikai és szociális befolyási rangsorát, amelynek alapjául a jelentéstevői szerepek, a vezetői posztok, továbbá a szavazási minták szolgálnak (VoleWatch Europe, 2020).

\section{Módszertan}

A fenti irodalom-összefoglaló mutatja, hogy - akárcsak a hegemónia méréséhez és meghatározásához - az EP-képviselők tevékenységének a leírására sincs egyszerủ módszertan és egyetlen átfogó mutató. A jelen tanulmány az Eulytix 2020-as éves jelentésének a módszertanára, valamint az elemzőcég adatbázisából a 2014-2019-es törvénykezési ciklusra vonatkozó adatsorra támaszkodva, három különböző szemszögből vizsgálja és rangsorolja a képviselőknek az adott időszakban folytatott politikai teljesítményét.

Az Európai Parlament 2014-2019-es törvénykezési ciklusra vonatkozó tevékenysége kapcsán az alábbi mutatószámok meghatározása a cél:

- német vezető EP-tisztségviselők számbavétele;

- „EP-képviselői aktivitási rangsor l”: az Európai Parlament kép viselőinek listája, az általuk benyújtott indítványok és módosítási javaslatok számának vizsgálata alapján;

- EP-képviselői aktivitási rangsor 2": a jelentéstevői (rapporteur) szerepkör vizsgálata - a szerepek megoszlásának elemzése tagállamokra lebontva (országesoportonként az EP-képviselők számára);

• EP-képviselői összeköttetési rangsor”: a képviselők együittmú ködésének szorosságát jelző lista, amely a közösen beterjesz tett módosító indítványok vizsgálata alapján állítja fel a rangsorukat. 


\section{Külïgyi Szemle}

A vezető $\mathrm{EP}$-tisztviselők - különösen a német nemzetiségűek számbavétele egy magától értetődő és egyszerű módszer az adott uniós intézményben fennálló hatalmi viszonyok feltérképezésére, még akkor is, ha elfogadjuk, hogy az Európai Parlamentben a pártlogika a legfontosabb rendező elv, s nem a nemzeti hovatartozás. Az EP világosan meghatározza, mely tisztviselők/pozíciók tekinthetôk vezető besorolásúnak. ${ }^{2}$ Három fontos formáció határozza meg ugyanis a működését: az Elnökség (Bureau), az Elnökök Értekezlete (Conference of Presidents), továbbá a Szakbizottsági Elnökök Értekezlete (Conference of Commiltee Chairs). Az első a szervezet mindennapi múködését biztosítja, amely az elnökből, az alelnökökből, valamint a quaestorokból álló testület. A másodiknak a legfontosabb célja az EP munkájának és a jogalkotási munka ütemezésének a megszervezése, és az elnökből, továbbá a képviselőcsoportok vezetőiből áll. A szakbizottságok közti együttmúködést az EP bizottsági elnökeit tömörítő a harmadik formáció segíti elő, és az Elnökök Értekezlete számára fogalmaz meg ajánlásokat.

Ezek alapján megállapítható, hogy a mindenkori elnök személye megkerülhetetlen, hiszen az intézmény politikai irányításáért, az általános politikai irányvonalának a kialakításáért és a gyakorlati megvalósításáért felelős. Az Európai Parlamentben a frakcióvezetők hasonló feladatokat látnak el, mint a nemzeti parlamentekben aktív kollégáik: ők fogják össze és koordinálják a frakciójuk munkáját - a politikai programok végrehajtása során kompromisszumra törekszenek. Az EP-frakciók vezetése felelósségteljes és politikai szempontból fontos feladat: a szürke politikai háttérmunkán kíviul ők szólalnak fel a plenáris ïléseken, ők közvetítik a frakciójuk álláspontját a sajtó és a választópolgárok felé. Nem véletlen, hogy a pozíció nem egy esetben jó ugródeszkának bizonyult más, fontosabb politikai posztok eléréséhez (például Manfred Weber néppárti frakcióvezetőből vált az Európai Bizottság elnökjelöltjévé).

Az Európai Parlamentben a szakbizottságokban folyik az érdemi po litikai és szakpolitikai munka, így az elnöki posztja sokrétú munkával és

2 Erről részletesebben lásd: Európai Parlamenı, 2019. 
komoly politikai felelősséggel jár. A szakbizottsági elnökök - egyebek mellett - meghatározó szerepet játszanak a szakbizottság többéves programjának a kialakításában, ők terelik mederbe a szakbizottsági jogalkotást, de arra is nagy a befolyásuk, hogy milyen ügyeket tűzzenek az ülések napirendjére, azokra, illetve a meghallgatásokra milyen biztosokat, szakértőket hívjanak meg. Emellett a szakbizottsági munka (irányítása) rengeteg politikai profilozási lehetőséget kínál: így a poszt jó lehetőséggel kecsegteti a birtokosait, hogy szélesebb körben ismertté váljanak, így (is) segíti őket előkészülni a politikai ranglistán megteendő esetleges következő lépésre (akár otthon, akár az EP-ben vagy más uniós intézményben).

Végüil, bár hivatalosan nem számít politikai vezető pozíciónak, mégis kiemelkedő jelentőséggel bír a fôtitkár is, aki az adminiszt ratív irányításért és a napi gyakorlati ügyekért felelős; a bürokrácia szürke eminenciásaként a napi hivatali teendôk intézésével az intézmény hosszú távú múködését biztosítja, s így a posztja politikai szem pontból is fontos (ráadásul az Európai Parlament esetében a fötitkári poszt általában része egy nagyobb intézményi-személyzeti alkunak).

A második feladat az aktivitási rangsor felállítása, amely az EP képviselők által jegyzett módosító indítványok alapján történik. Ebből kiderül, hogy kik voltak a 2014-2019-es törvénykezési időszak során a legaktívabbak. A jelentéstevői (második aktivitási) rangsor felállításához a jelentéstevő (rapporleur) szerepkörének a vizsgálata szüikséges, az összeköttetési rangsor alapját pedig a közösen jegyzett módosító indítványok képezik. Mindezek elemzése után beazonosíthatóvá válik, hogy a német képviselők az élen helyezkednek-e el e rangsorokban. Feltételezve, hogy Németország hegemóniája tetten érhető az európai intézményrendszer egészében, így az Európai Parlamentben is, az várható, hogy a német képviselők előkelő helyeken fognak szerepelni az aktivitást és az összeköttetést mérő listákon.

Az aktivitási rangsor az EP-képviselők által (a vizsgált időszak ban) beterjesztett módosító indítványok összesítése alapján áll össze, és bizonyos feltételezéseket tartalmaz. Tekintve, hogy az EP eljárás rendje szerint a javaslatokat egy vagy több képviselő is benyújthatja, 


\section{Külïgyi Szemle}

az Eulytix által kifejlesztett és kidolgozott - a jelen tanulmányban is alkalmazott - módszertan azt feltételezi, hogy a többek által jegyzett módosító indítványhoz az azt aláírók hasonló arányban járultak hoz zá. Éppen ebből következik, hogy ilyen esetben az adott képviselő aktivitási mérlege a módosító javaslatot beadók számának a reciprokával növekszik.

A jelentéstevői rangsor hasonló elven alapszik: a vizsgálat alá vont törvénykezési ciklus összes (több mint háromezer) parlamenti jelen tésének az összegzése alapján rangsorol - csak a jelentéstevők nemzetisége alapján, függetlenül attól, hogy milyen típusú és politikailag milyen súlyú dossziékról volt szó.

A negyedik típusú mutató, az ún. összeköttetési rangsor az EPképviselőket a többedmagukkal beterjesztett módosító indítványaik alapján vizsgálja. Módszertani szempontból némileg összetettebb az aktivitási rangsornál: az Eulytix módszertana szerint a képviselők közti kapcsolat szorosságát az adott indítványt közösen jegyzők szá mának az élesen csökkenő függvénye mutatja meg, majd a közös javaslatok aggregálása alapján áll össze a képviselők közti összeköttetés erőssége, amely alapján a rangsorolás lehetővé válik (Kovács és Kocsis, 2021). Következésképpen e módszertan egy olyan összeköttetési hálózatot hoz létre, amely figyelembe veszi az EP-képviselők közötti együittmúködés gyakoriságát, és - az egyes módosító javaslatok esetén a beterjesztők számának figyelembevételével - kellő jelentőséget tulajdonit a kapcsolatnak is. Nem kérdéses, hogy némi kompromiszszumra is szükség van hozzá: a valóságban nem minden módosítás rendelkezik azonos (politikai) súllyal, és minden bizonnyal szorosabb kapcsolatok jönnek létre a fontosabb indítványok előterjesztése ese tén. Mivel azonban a módosító indítványok jelentősége között objektív módon lehetetlen különbséget tenni, az egyes jellemzők szerinti csoportosításuk csorbítaná a rangsor hitelességét. (A módszertanról bővebben lásd az Eulytix 2020-as éves jelentését: Kovács és Kocsis, 2021). 


\section{Eredmények}

Ami az Európai Parlamenten belüli vezető német tisztségviselóket illeti, világosan látható a németek túlsúlya. Az EP-nek a nyolcadik cik lusa (2014-2019) jelentős részében (2014 júliusától 2017. januárig) német elnöke volt (Martin Schulz), és végig német fötitkár szolgált (Klaus Welle, aki nem mellesleg 2009 óta tölti be folyamatosan a funkciót). A képviselettel bíró legnagyobb pártcsaládoknál ugyancsak német vezetés figyelhető meg: a néppárti frakciót 2014-től Manfred Weber vezeti 2018-2019-ben Udo Bullmann állt a szocialista frakció élén, a Zöldek társelnöke Ska Keller volt, a Baloldalt (The Left) pedig Gabriele Zimmer vezette a teljes időszakban. Összességében kijelenthető, hogy az EP-frakciókban számottevő a német vezetés, de a cikluson belül olyan időszak is volt, amikor a nyole EP-képviselôcsoport közül négyet német képviselő vezetett. A frakcióvezetésnél kevésbé fajsúlyos, ám politikailag mégis jelentôs a szakbizottsági elnökök pozíciója, amelyek tekintetében már nem volt ennyire szembetúnő a német dominancia. A 2014-2019-es törvénykezési ciklus során 19 állandó szakbizottság mûködött, és az időszak első felében csupán négyet vezetett német képviselô. Igaz, azok éppen a legfontosabb (a méretük szempontjából a legnagyobb) szakbizottságok voltak, például a Külüigyi Bizottság vagy a Nemzetközi Kereskedelmi Bizottság. A ciklus második felében ötre bővïlt a német szakbizottsági elnökök száma.

A fenti eredmények természetesen nem függetlenek az Euró pai Parlamentben a mandátumok kiosztásához használt D’Hondtmódszertől, amely a legmagasabb átlagokkal számol. Ennek annyiban van jelentősége, hogy a nagyobb pártoknak kedvez, s a - lakosai száma alapján eleve a legnépesebb - német képviselői kontingens túlnyomó többsége hagyományosan az EP nagy pártcsaládjaihoz tartozik. Mindezt erósíti, hogy a D'Hondt-módszer alkalmazása az egyes pártcsaládokon belül is bevett szokás a pozíciók - az EP-alelnökök, a szakbizottsági elnökök, a szakbizottsági elnökhelyettesek elosztásánál, így a csak néhány nagyobb pártcsaládba tömörülő né met képviselók általában jó eséllyel pályázhatnak valamilyen vezető posztra. (A módszernek az EP-n belüli gyakorlati alkalmazásáról lásd: Kotanidis, 2019.) 


\section{Külïgyi Szemle}

\section{EP-képviselöi aklivilási rangsor 1}

Az aktivitási rangsor első verziója az EP-képviselők által benyújtott különböző módosító indítványok összesítése és aggregálása alapján méri a küldöttek aktivitását. Ez alapján az látható, hogy korántsem a németek voltak a legaktívabbak az Európai Parlament 2014-2019-es törvénykezési ciklusa során (lásd az 1. táblázatot).

\section{1. táblázat ${ }^{3}$}

A 20 legaktívabb német EP-képviselő és az összetett helyezésük az aktivitási rangsorban (2014-2019)

\begin{tabular}{|c|c|c|c|c|c|}
\hline Név & $\begin{array}{l}\text { Kép- } \\
\text { viselö- } \\
\text { csoport }\end{array}$ & $\begin{array}{l}\text { Aktivi- } \\
\text { tási } \\
\text { sorrend }\end{array}$ & Név & $\begin{array}{c}\text { Kép-- } \\
\text { viselö- } \\
\text { csoport }\end{array}$ & $\begin{array}{l}\text { Aktivi- } \\
\text { tási } \\
\text { sorrend }\end{array}$ \\
\hline Julia Reda & $\begin{array}{c}\text { Greens/ } \\
\text { EFA }\end{array}$ & 16. & Martin Häusling & $\begin{array}{c}\text { Greens/ } \\
\text { EFA }\end{array}$ & 76. \\
\hline Sven Giegold & $\begin{array}{c}\text { Greens/ } \\
\text { EFA }\end{array}$ & 17. & Jan Philipp Albrecht & $\begin{array}{c}\text { Greens/ } \\
\text { EFA }\end{array}$ & 108. \\
\hline Markus Ferber & EPP & 21. & Monika Hohlmeier & EPP & 116. \\
\hline Helmut Scholz & GUE/NGL & 27. & Christian Ehler & EPP & 128. \\
\hline Cornelia Ernst & GUE/NGL & 35. & Axel Voss & EPP & 136. \\
\hline Maria Heubuch & $\begin{array}{c}\text { Greens/ } \\
\text { EFA }\end{array}$ & 40 & Andreas Schwab & EPP & 155. \\
\hline Terry Reintke & $\begin{array}{c}\text { Greens/ } \\
\text { EFA }\end{array}$ & 49. & Arne Gericke & $\mathrm{ECR}$ & 164. \\
\hline Ska Keller & $\begin{array}{c}\text { Greens/ } \\
\text { EFA }\end{array}$ & 58. & Ulrike Müller & ALDE & 184. \\
\hline Beatrix von Storch & EFDD & 65. & Evelyne Gebhardt & S\&D & 186. \\
\hline Bernd Lucke & ECR & 70 & Klaus Buchner & $\begin{array}{c}\text { Greens/ } \\
\text { EFA }\end{array}$ & 187. \\
\hline
\end{tabular}

Megjegyzés: ALDE = Liberálisok és Demokraták Szövetsége Európáért; ECR = Európai Kon zervatívok és Reformerek; EFDD = Szabadság és Közvetlen Demokrácia Európája; EPP Európai Néppárt; Greens/EFA = Zöldek/Európai Szabad Szövetség; GUE/NGL = Egysé ges Európai Baloldal/Északi Zöld Baloldal; S\&D = Szocialisták és Demokraták Progresszív Szövetsége.

3 Forrás: az Eulytix (Kovács és Kocsis, 2021) adatai alapján saját szerkesztés. 
Sôt, a legaktívabb 15 képviselỏ között egyáltalán nincs német (lásd a 3. táblázatot), az első 50-ben hét található, az élen álló száznak pedig csupán hozzávetőleg a tizede érkezett Németországból. Ez azt is jelenti, hogy a túlnyomó többségük a „top 100-on” kívül esik, mi több, 56 német EP-képviselő az összesített rangsor második felébe kerülhetett csak be.

Ez a rangsor azt is megmutatja, hogy nincs szoros összefüggés az aktivitás (a benyújtott módosító indítványok száma) és a politikai pártcsaládhoz tartozás között (lásd a 3. táblázatot). A legaktívabb hat képviselô mindegyike eltérő politikai háttérrel rendelkezik (egy függetlenként ült az EP-ben, a többiek más és más frakcióban). Ugyanerről árulkodik az is, hogy a legaktívabb húsz képviselő közuil négy független. A németekre is érvényes ez a megfigyelés: azok, akik bekerültek a legaktívabb száz EP-képviselő közé, nagyjából az összes pártcsalád valamelyikét erősítik, bár némi zöldpárti túlsúly figyelhető meg esetüikben.

Habár a jelen aktivitási rangsor kizárólag a benyújtott módositó indítványok száma alapján méri az EP-képviselők aktivitását, nem lehet megfeledkezni arról, hogy a tevékenységük, a teljesítményük és az aktivitásuk egyéb fontos dimenziókon és lépéseken keresztuil is érvényesülhet. Ezt mutatja, hogy a prominens képviselők általában nem foglalnak el előkelő helyet az aktivitási rangsorban - és ez az ismertebb német személyiségekre is igaz (talán csak Ska Keller zöldpárti frakcióvezető a kivétel, aki az 58. az aktivitási ranglistán). Néhány példa erre: a Külïigyi Bizottság befolyásos német elnöke, David McAllister csupán az 572., Manfred Weber néppárti frakcióvezető (akit pártja a 2019-es EP-választások után az Európai Bizottság elnöki pozíciójára is jelölt) csak a 760., a rangsor egyik utolsó helyezettje. Martin Schulz, aki 2017-ig az EP elnöke volt, meg se jelenik az aktivitási rangsorban - ami azt jelenti, hogy egyetlen módosító indítványt sem jegyzett a vizsgált időszakban. Ezek a példák is alátámasztják, hogy hiba lenne az EP-képviselők jogalkotási (módosító indítványokat jegyző) aktivitását a kizárólagos tevékenységüiknek tekinteni. 


\section{Külïgyi Szemle}

Az aktivitási rangsor alapján összességében az látható, hogy a né metek a vizsgált törvénykezési időszakban - jogalkotási szempontból nem tartoztak a legtermékenyebb képviselők közé.

\section{EP-képviselói aktivilási rangsor 2}

A második aktivitási rangsor az EP-képviselők jelentéstevői szere pének összesítése alapján készüil (és nem tesz különbséget az egyes jelentések típusa között, azaz azt feltételezi, hogy mindegyik ugyanolyan súlyú). Az Eulytix által készitett adatelemzés (lásd Kovács és Kocsis, 2021, 15. melléklet, áttekintő táblázat) meglehetősen egyértelmú képet mutat e szerepek alakulásáról, amit az 1. ábra szemléltet. A grafikon bal oldali tengelye a jelentéstevők számát, a jobb oldali a jelentéstevők egy képviselőre vetített arányát mutatja, tagállamonkénti bontásban.

\section{1. ábra ${ }^{4}$}

Az EP-jelentéstevők száma és aránya tagállami bontásban

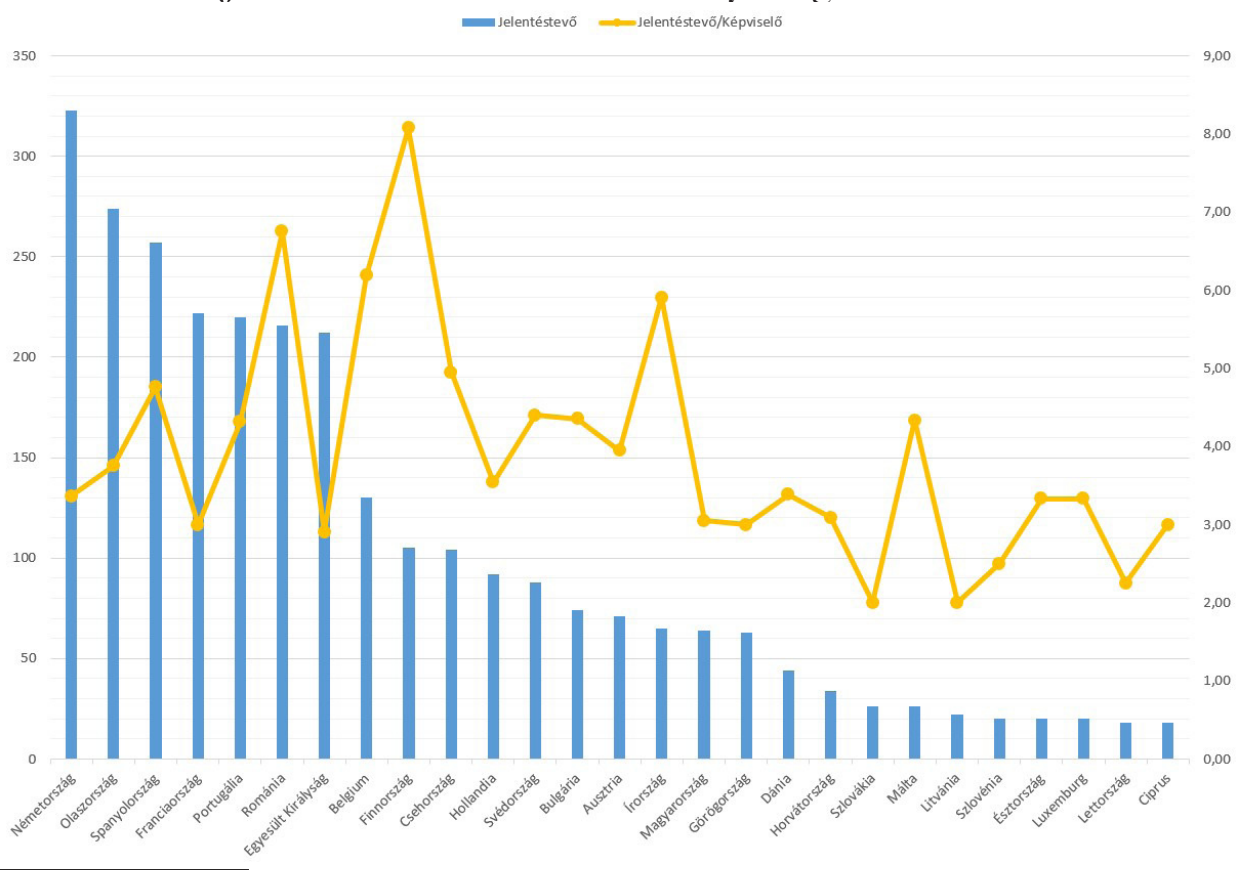

4 Forrás: az Eulytix (Kovács és Kocsis, 2021) adatai alapján saját szerkesztés. 
Az adatokból és a szemléltető ábrából jól látszik, hogy a vizsgált törvénykezési időszakban a német képviselők vállalták a legtöbb jelentéstevói szerepet: öt év alatt több mint háromszázat. Az ábráról az is leolvasható, hogy az egyes tagállamok által delegált képviselők száma meghatározó jelentőségű abban, hogy hány jelentéstevői szerepet kaptak a vizsgált időszakban. Ennek megfelelően e tekintetben Németországot a további nagy népességű (és így több EP-képviselőt delegáló) tagállamok követik (Olaszország, Spanyolország, Franciaor szág és Lengyelország). Tehát a jelentéstevői szerepek számbeli vizsgálata csalóka, hiszen az Európai Parlamentbe a legtöbb képviselót delegáló állam Németország, így hozzá kötődik a legtöbb jelentéstevői szerep is.

Némileg árnyaltabb képet kapunk, ha a jelentéstevők számát az adott tagállam képviselőinek a számával arányosítjuk. Ezzel megkapjuk az egy EP-képviselőre eső jelentéstevői szerepek számát (a grafikonon ezt szemlélteti a sárga vonal, továbbá a jobb oldali tengely). E szempontból Finnország képviselói tekinthetők a legaktívabbaknak: egy személyre több mint nyolc jelentéstevői szerep jutott. De e tekintetben kiemelkedtek a román és a belga képviselők is (fejenként több mint hat jelentéstevói szerep). A német képviselők ez alapján csupán a középmezőnybe kerültek: 3,3 jelentéstevői szerep esett egy fơre, és ezzel a rangsor 16. helyét foglalták el.

Bár fontos ismét hangsúlyozni, hogy a jelen összeállítás nem tesz különbséget az egyes jelentések típusa között, azaz kvázi egyenlő fontosságot tulajdonít mindegyiknek (ami a valóságban természetesen nem állja meg a helyét), így is megállapítható, hogy a német EP-delegáció csupán a nagy létszáma miatt tudhatta magáénak a legtöbb jelentéstevői szerepet a 2014-2019-es időszakban. Az egyes képviselők aktivitását akkurátusabban mérő, egy főre jutó jelentéstevői szerepek száma azt mutatja, hogy a német képviselők csupán a középmezőnybe tartoznak, s korántsem ők vállalják a legtöbb jelentéstevői pozíciót. 


\section{Külïgyi Szemle}

\section{EP-képviselói összeköttetési rangsor}

Az összeköttetési rangsor (2. táblázat), ahogy arról már szó volt, az EP-képviselők által közösen jegyzett módosító indítványok alapján készített sorrend. Az itt kialakult kép némileg eltér az első aktivitási rangsortól: német képviselő egyáltalán nem szerepel az első ötven helyezett között (az első az 56. helyen található), és csupán hat jelenik meg az első száz között. Mindezt figyelembe véve kijelenthető, hogy a németek nem tartoznak a többiekkel leginkább összekötött képviselők közé, azaz más tagállamok képviselői sokkal inkább hajlanak arra, hogy a módosító indítványaikat közösen terjesszék be (ez leginkább a különböző munkamódszerekbe ad betekintést, ami egyébként lehet akár kulturális sajátosság is). A rangsor első szakaszát a dél-európai képviselők sajátítják ki: a leginkább összekötött tíz EP-képviselőből öt spanyol, kettő pedig olasz. A rangsor elsô húsz helyén álló képviselő közül hat spanyol, három olasz, három brit és két belga található (lásd a 3. táblázatot).

\section{2. táblázat ${ }^{5}$}

A 20 leginkább összekötött német EP-képviselő és az összetett helyezéseik az összeköttetési rangsorban (2014-2019)

\begin{tabular}{|l|c|c|c|c|c|}
\hline \multicolumn{1}{|c|}{ Név } & $\begin{array}{c}\text { Kép- } \\
\text { viseló- } \\
\text { csoport }\end{array}$ & $\begin{array}{c}\text { Össze- } \\
\text { köttetési } \\
\text { sorrend }\end{array}$ & Név & $\begin{array}{c}\text { Kép- } \\
\text { viseló- } \\
\text { csoport }\end{array}$ & $\begin{array}{c}\text { Össze- } \\
\text { köttetési } \\
\text { sorrend }\end{array}$ \\
\hline Sabine Verheyen & EPP & 56 & Martina Werner & S\&D & 175 \\
\hline Ulrike Müller & ALDE & 85 & Markus Pieper & EPP & 198 \\
\hline Fabio De Masi & GUE/NGL & 88 & Gesine Meissner & ALDE & 202 \\
\hline Beatrix von Storch & EFDD & 94 & Helmut Scholz & GUE/NGL & 205 \\
\hline Julia Reda & $\begin{array}{c}\text { Greens } \\
\text { EFA }\end{array}$ & 96 & Maria Noichl & S\&D & 210 \\
\hline Arne Gericke & ECR & 97 & Sven Giegold & Greens & EFA \\
\hline Monika Hohlmeier & EPP & 127 & Axel Voss & EPP & 222 \\
\hline Jo Leinen & S\&D & 145 & Joachim Schuster & S\&D & 227 \\
\hline Bernd Lucke & ECR & 146 & Peter Jahr & EPP & 230 \\
\hline Maria Heubuch & Greens/ & 156 & Sven Schulze & EPP & 235 \\
\hline
\end{tabular}

5 Forrás: az Eulytix (Kovács és Kocsis, 2021) adatai alapján saját szerkesztés. 
Az első aktivitási mutatónál kapott eredménytől eltérően itt, úgy tűnik, a pártcsaládhoz való tartozás fontosabb szerepet tölt be az EPképviselők közti, a módosító indítványok együttes benyújtását célzó együttmûködések esetében. Az elsô tíz leginkább összekötött EP-képviselô mindegyike valamelyik nagyobb pártcsalád frakciójához tartozik, nyolcuk a Szocialisták és Demokratákhoz (S\&D). Ebből arra lehet következtetni, hogy a közösen beterjesztett módosító indítványok egy gyakran használt politikai eszközként szolgálnak az S\&D frakció számára, amit az is megerősít, hogy a száz leginkább összekötött képviselő közuil a legtöbb (35 fô) annak a tagja (míg csupán 13 az EPP-é és 15 az ALDE-é). Érdekesség, hogy a pártcsaládhoz tartozás fontossága a német képviselők esetében nem érhető tetten: az említett százas listán szereplő hat német mindegyike más frakcióban ïl.

Ugyanakkor az összeköttetési rangsor böngészésekor is szembe tủnő, hogy a prominens német EP-képviselők jellemzően nem szerepelnek annak az elején. A már korábban említett Ska Keller zöldpárti társ-frakcióvezető csupán az 527., David McAllister (a Külügyi Bizottság elnöke) a 627., míg Manfred Weber néppárti frakcióvezető a 675. Mivel a közismert német EP-képviselők az első aktivitási rangsorban sem töltöttek be kiemelkedő szerepet, az itteni (viszonylag alacsony) helyezései sem tekinthetők meglepőnek.

\section{Következtetések, a tanul mány korlátai}

A jelen tanulmány kimutatta, hogy a német EP-képviselők igen előkelő helyen szerepelnek az Európai Parlament vezető tisztségeinek a betöltése szempontjából, ugyanakkor az aktivitási és az összeköttetési mutatókból az derül ki, hogy a módosító indítványok jegyzése alapján nem tekinthetők sem a legaktívabbaknak, sem a leginkább összekötötteknek, ráadásul a jelentéstevői szerepek tekintetében sem éppen átlagon felüli aktivitásúak. Következésképp az a feltételezett és immár a németek által is vallott státusz, miszerint Németország Európa hegemónja (Wir sind der Hegemon), ${ }^{6}$ nem tükröződik az Európai Parlament tevékenységét vizsgáló mutatókon.

6 Lásd a már idézett Herfried Münklernek a Frankfurler Allgemeine Zeitungban közölt véleménycikkét (Münkler, 2015b). 


\section{Külïgyi Szemle}

Bár némileg más metodológián alapul, de a VoteWatch Europe is alátámasztja a fenti vizsgálatok eredményét. A brüsszeli székhelyű intézet a jelentéstevői szerepek, a vezetői posztok, továbbá a szavazási minták alapján rangsorolja az EP-képviselőket, s a legutóbbi (a 2020 as évre vonatkozó) elemzéséből kiderül, hogy az aggregált és az országokra vetített eredmények alapján Németország korántsem tekinthető az EP egyik legbefolyásosabb államának. A két vizsgált dimenziót (a politikai és a szociális befolyást) vegyítve a VoteWatch Europe csupán a kilencedik helyen rangsorolja az uniós országok körében, ami egyáltalán nem tekinthető hegemón szerepkörnek (VoteWatch Europe, 2020).

Fontos ugyanakkor felhívni a figyelmet a jelen tanulmányban alkalmazott módszertan gyengeségeire, közülïik is az eredményeknek a tagállami hegemóniára való értelmezésének a korlátaira:

- Az első probléma, ahogy azt már korábban említettem, az Eu rópai Parlamenttel kapcsolatos jelen elemzés kizárólag egy na gyobb vizsgálat részeként tud a hegemónia kutatásához hozzá járulni (lásd a bevezetést). Az EP nem tekinthető a tagállami érdekérvényesítés elsődleges fórumának, így az intézménnyel és a képviselőivel kapcsolatos következtetések korlátozott magyarázóerôvel bírnak az egyes uniós tagállamok befolyása tekintetében. Azonban nem létezik egy univerzális módszertan az EP-képviselők aktivitásának a pontos meghatározására, hiszen az egy többdimenziós tevékenység, amely nem szűkíthető le a módosító indítványok és a jelentéstevői szerepek vizsgálatára. Az EP-képviselők munkájának csupán a törvénykezési és a szakbizottsági dimenziójában játszik (igen fontos) szerepet a módosító indítványok benyújtása, de ők számos egyéb funkciót is ellátnak, amelyeket a most alkalmazott aktivitási rangsor nem képes megragadni.

- Egy másik gyengeség, hogy a vizsgálat csupán egyetlen tör vénykezési ciklust ölel fel, így az abból származó adatok magyarázó ereje némileg korlátozott. Több ciklus adatainak az elemzése értelemszerủen megbízhatóbb eredményre vezetett volna. 
Végül fontos megemlíteni, hogy a vizsgálat jellegéből adódóan nem lehet küiönbséget tenni az egyes jelentések típusa és - ennek következtében - a (politikai) súlya között. Az Európai Parlament által elfogadott törvénytervezetek, jelentések, vélemények azonban az adott téma politikai súlyától függően más és más súllyal bírnak, így a valóságban nagy eltérések vannak az egyes dossziékat menedzselő jelentéstevők fontossága között. A vizsgálat ezt a fajta differenciálódást nem tudja megjeleníteni.

A tanulmány célja az volt, hogy (egy átfogó kutatás egyik leágazásának keretei között) az EU-n belïli német hegemónia nyomára bukkanjon az Európai Parlamenten belül, azaz statisztikai elemzéssel bizonyítsa, hogy a német EP-képviselők számítanak-e a legbefolyásosabbaknak és a legaktívabbaknak a legnagyobb demokratikus legitimitással bíró (azaz az egyetlen közvetlenül választott) uniós intézményben. Az adatsorok alapján megalkotott mutatók arra világítanak rá, hogy a vizsgált időszakban korántsem a német képviselők voltak a legaktívabbak (pl. nem ők vállaltak jelentéstevői szerepet a legnagyobb arányban), nem ők rendelkeztek a legszorosabb összeköttetési hálóval. Ez azt bizonyítja, hogy a német hegemónia egyáltalán nem volt egyértelmű az Európai Parlament 2014-2019-es törvénykezési ciklusában.

\section{Irodalomjegyzék}

Baranyi Márton (2021). Hegemón-e Németország? A némel hegemónia gyakorlati megnyilvánulásai az Európai Unió intézményrendszerében. Doktori disszertáció. Budapest: Budapesti Corvinus Egyetem, Nemzetközi Kapcsolatok és Politikatudományi Doktori Iskola. A letöltés ideje: 2021. december 10. http://phd.lib.uni-corvinus.hu/1185/2/baranvi marton thu.pdf.

Benczes István (2017). Regionális hegemón-e Németország? Külgazdaság, $61(7-8), 3-27$.

Benczes István (2018). Kiegyensúlyozás, mélyülés, hegemónia - Az Európai Unió és a realizmus. Külügyi Szemle, (1), 81-105. 


\section{Külïgyi Szemle}

Brack, Nathalie és Costa, Olivier (2018). Introduction: the European Parliament at a Crossroads, The Journal of Legislative Studies, 24(1), 1-10. Bulmer, Simon és Paterson, William (2013). Germany as the EU's Reluctant Hegemon? Of Economic Strenght and Political Constraints, Journal of European Public Policy, 20(10), 1387-1405.

Bulmer, Simon és Paterson, William (2018). Germany and the European Union: Europe's Reluctant Hegemon? London: Red Globe Press.

Chiru, Mihail (2020). Loyal Soldiers or Seasoned Leaders? The Selection of Committee Chairs in the European Parliament, Journal of European Public Policy, 27(4), 612-629.

Crawford, Beverly (2015). German Power and Embedded Hegemony in Europe. In Sara Colvin (szerk.), The Roulledge Handbook of German Politics and Culture (329-348. o.).

Európai Parlament (2019). Who's Who: Overview of Parliament's Leadership. A letöltés ideje: 2021. június 18. https://www.europarl. europa.eu/news/en/headlines/priorities/parliament-leadership2019/20190705STO56304/who-s-who-overview-of-parliament-sleadership.

Faas, Thorsten (2002). Why Do Meps Defect? An Analysis of Party Group Cohesion in the 5th European Parliament. European Inlegration Online Papers (EIoP), 6(20).

Fertő Imre és Kovács Attila (2019). The Hidden Drivers of the Legislation of the Common Agricultural Policy - The Case of the 2013 CAP Reform. Bulgarian Journal of Agricultural Science, 25(2), 223-231.

Fertő Imre, Kóczy László, Kovács Attila és Sziklai Balázs (2020). The Power Ranking of the Members of the Agricultural Committee of the European Parliament, European Review of Agricultural Economics, 47(5), 1-23.

Graf Kielmansegg, Peter (2017). Deutschland und Europa: Aspekte einer schwieriger gewordenen Beziehung. ZSE Zeilschrift für Staals- und Europawissenschafien, 15(2-3), 485-500.

Hettyey András (2019). Hegemónia helyell - Magyar-némel kapcsolalok 1990-2002 közöıl, Budapest: L'Harmattan.

Hix, Simon (2002). Parliamentary Behavior with Two Principals: Preferences, Parties, and Voting in the European Parliament. American Journal of Political Science, 46(3), 688-698.

Hix, Simon, Noury, Abdul és Roland, Gerard (2005). Power to the Parties: Cohesion and Competition in the European Parliament 1979-2001. British Journal of Political Science, 35(2), 209-234. 
Hix, Simon, Noury, Abdul és Roland, Gerard (2006). Dimensions of Politics in the European Parliament. American Journal of Political Science, 50(2), 494-511.

Hix, Simon, Noury, Abdul és Roland, Gerard (2009). Voting Patterns and Alliance Formation in the European Parliament. Philosophical Transactions of the Royal Society B: Biological Sciences, 364(1518), 821831.

Kaeding, Michael és Obholzer, Lukas (2012). Pulling the Strings: Party Group Coordinators in the European Parliament. EIPAScope, (1).

Keohane, Robert (1984). After Hegemony - Cooperation and Discord in the World Political Economy. Princeton: Princeton University Press.

Kornelius, Stefan (2010). Hegemon wider Willen, Süddeulsche Zeilung. A letöltés ideje: 2021. április 15. https://www.sueddeutsche.de/politik/ euro-krise-hegemon-wider-willen-1.1028932-0\#seite-2.

Kotanidis, Silvia (2019). Understanding the d'Hondt Method-Allocation of Parliamentary Seats and Leadership Posilions. European Parliamentary Research Service, Briefing. A letöltés ideje: 2021. június 18. https:// www.europarl.europa.eu/RegData/etudes/BRIE/2019/637966/EPRS BRI(2019)637966_EN.pdf.

Kovács Attila és Kocsis Levente (2021). Eulytix Annual Report, European Parliament 2019-2020. EUlylix.eu. A letöltés ideje: 2021. február 28. https://eulytix.eu/annual-report/.

Kundnani, Hans (2014). The Paradox of German Power. London: Hurst \& Company.

Morisse-Schilbach, Melanie (2011). "Ach Deutschland!": Greece, the Euro Crisis, and the Costs and Benefits of Being a Benign Hegemon. Internationale Politik und Gesellschaft, (1).

Münkler, Herfried (2015a). Macht in der Mille - Die neuen Aufgaben Deutschlands in Europa, Hamburg: Körber Stiftung.

Münkler, Herfried (2015b). Wir sind der Hegemon. Frankfurter Allgemeine Zeitung. A letöltés ideje: 2021. június 18. https://www.faz.net/aktuell/ feuilleton/debatten/europas-zukunft/einzusehen-deutschland-isteuropas-zentralmacht-13760335.html.

Nagy Sándor Gyula (2013). The Internationalization of the Spanish SME Sector. Sociely and Economy, 35(1), 71-86.

Pedersen, Thomas (2002). Cooperative Hegemony: Power, Ideas and Institutions in Regional Integration. Review of International Studies. 28(4), 677-696. 


\section{Külïgyi Szemle}

Proissl, Wolfgang (2010). Why Germany Fell Out of Love with Europe. Brüsszel: Bruegel Essay and Lecture Series.

Schönberger, Christoph (2012). Hegemon wider Willen - Zur Stellung Deutschlands in der Europäischen Union, Merkur, 66(752), 1-8.

Siljak, Dzenita és Nagy Sándor Gyula (2018). The Effects of the Crisis on the Convergence Process of the Western Balkan Countries Towards the European Union. Sociely and Economy, 30(1), 105-124.

Thierse, Stefan (2019). Policy Entrepreneurship in the European Parliament:

Reconsidering the Influence of Rapporteurs. Journal of European Public Policy, 26(2).

VoteWatch Europe (2020). Influence Index 2020: Top 100 Most Politically Influential MEPs. A letöltés ideje: 2021. március 1. https://www. influenceindex.eu/influence-analysis/.

Wilson, Steven és Thomme Jack van (2016). Policy Leadership and Re Election in the European Parliament. Journal of European Public Policy, 23(8), 1-22. 
ay

$\forall \nabla$

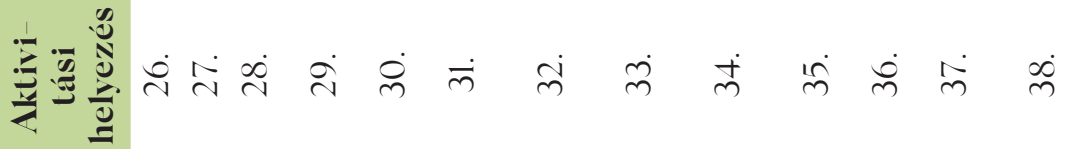

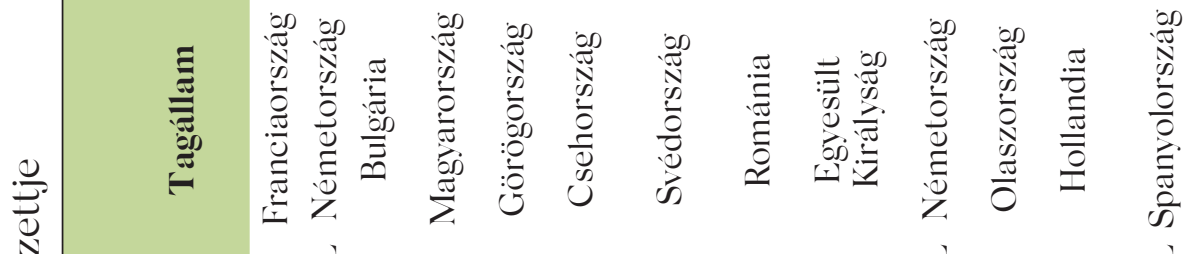

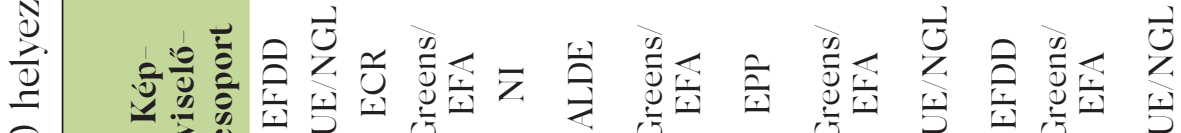

in

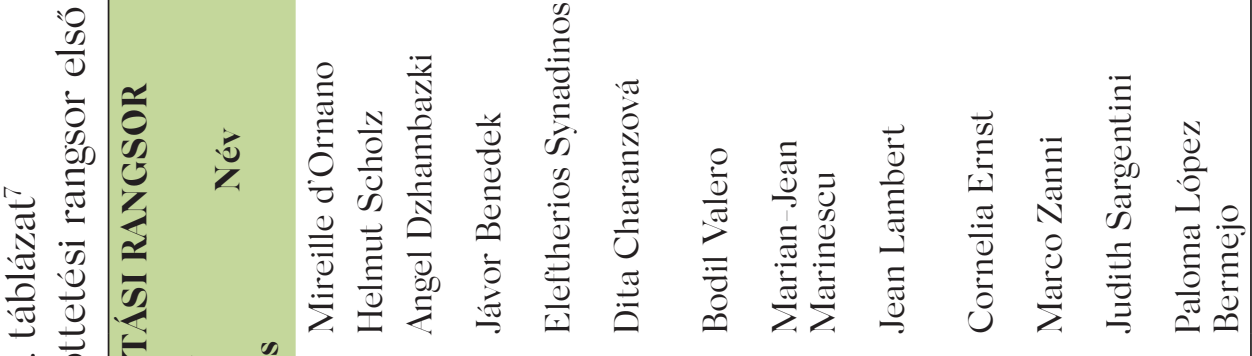
r

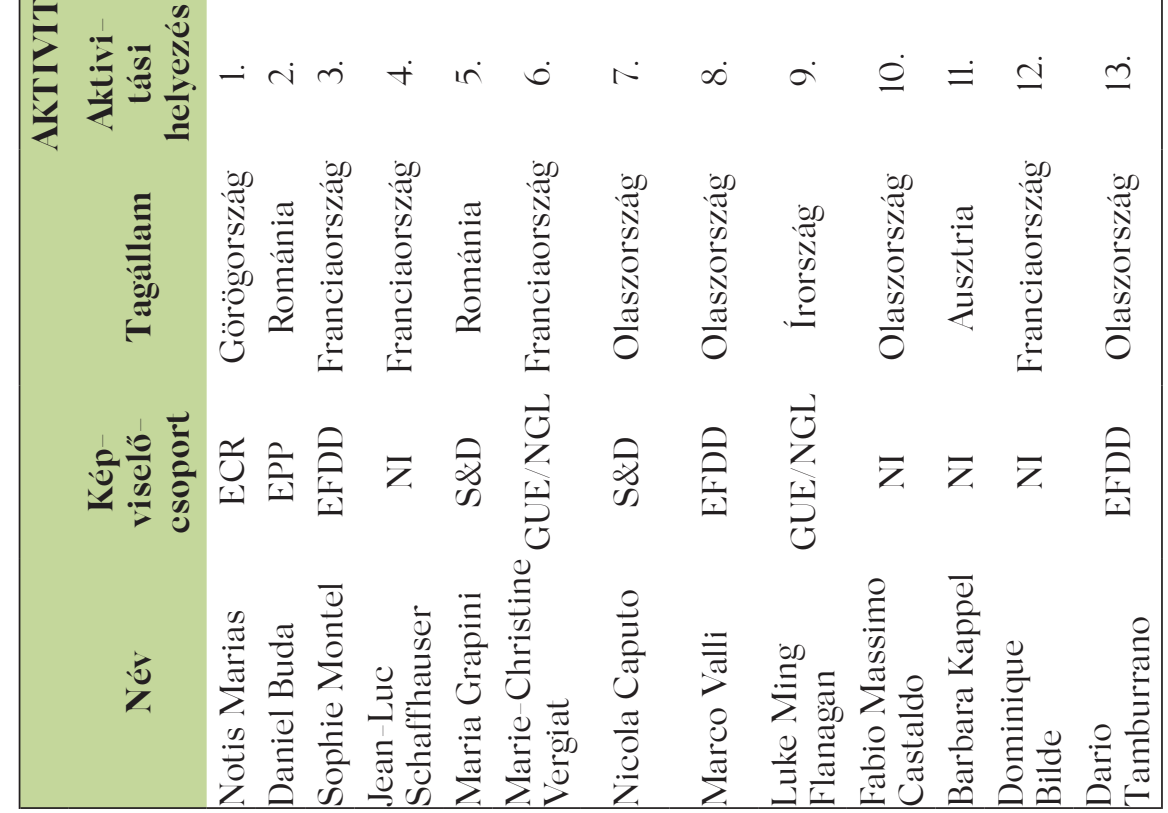


Külïgyi Szemle

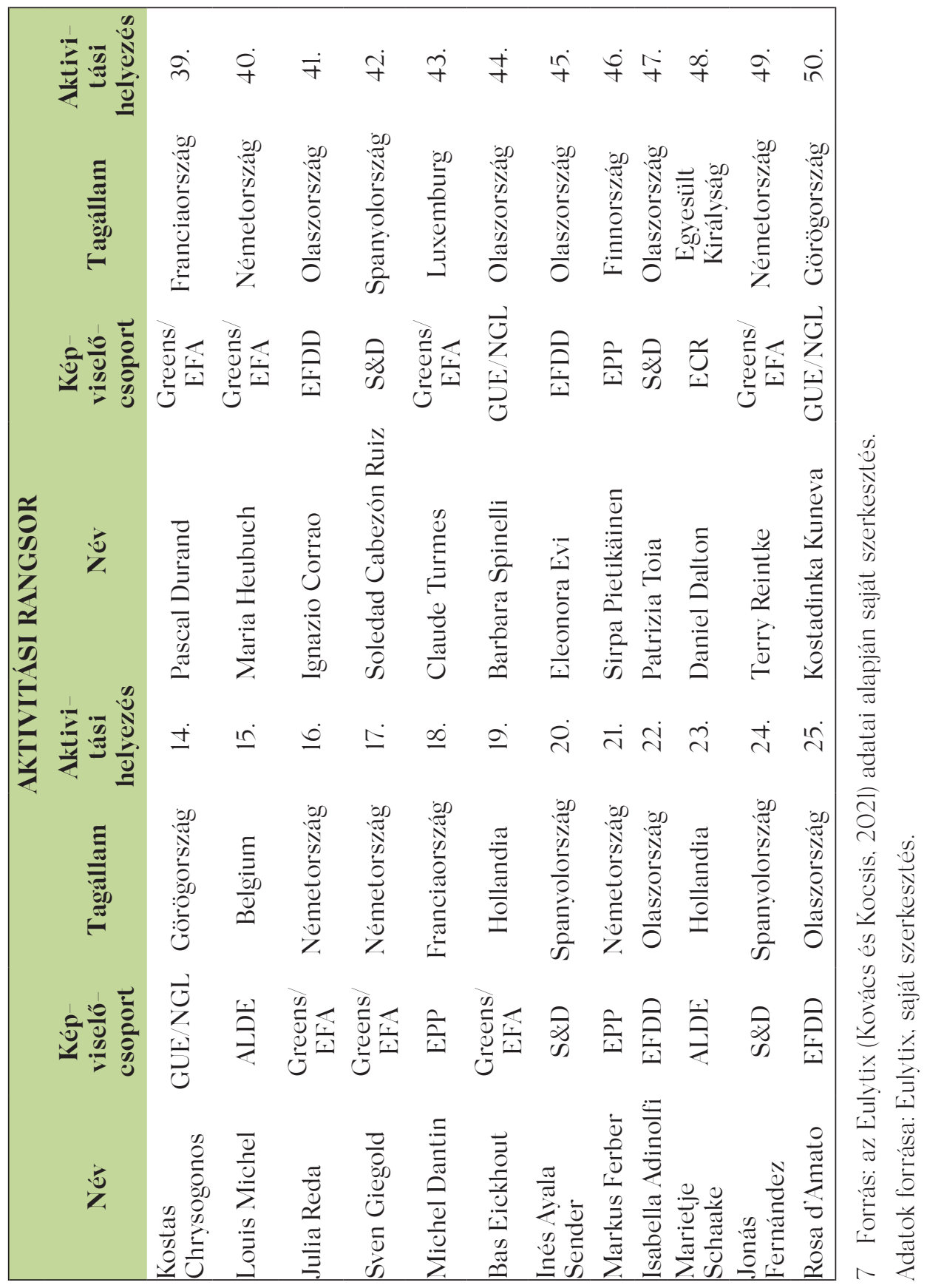




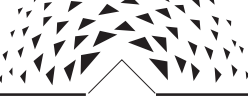

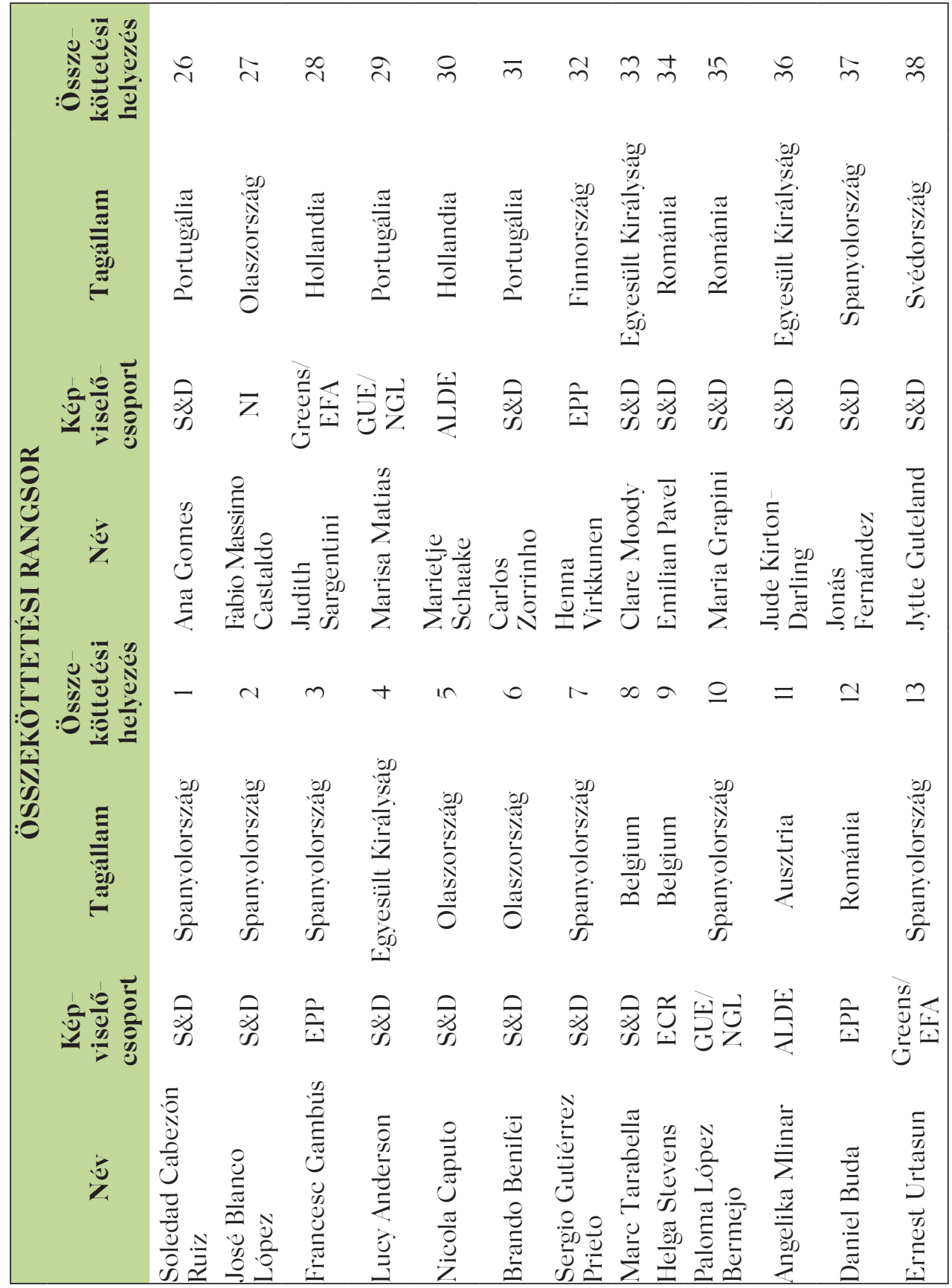


Külïgyi Szemle

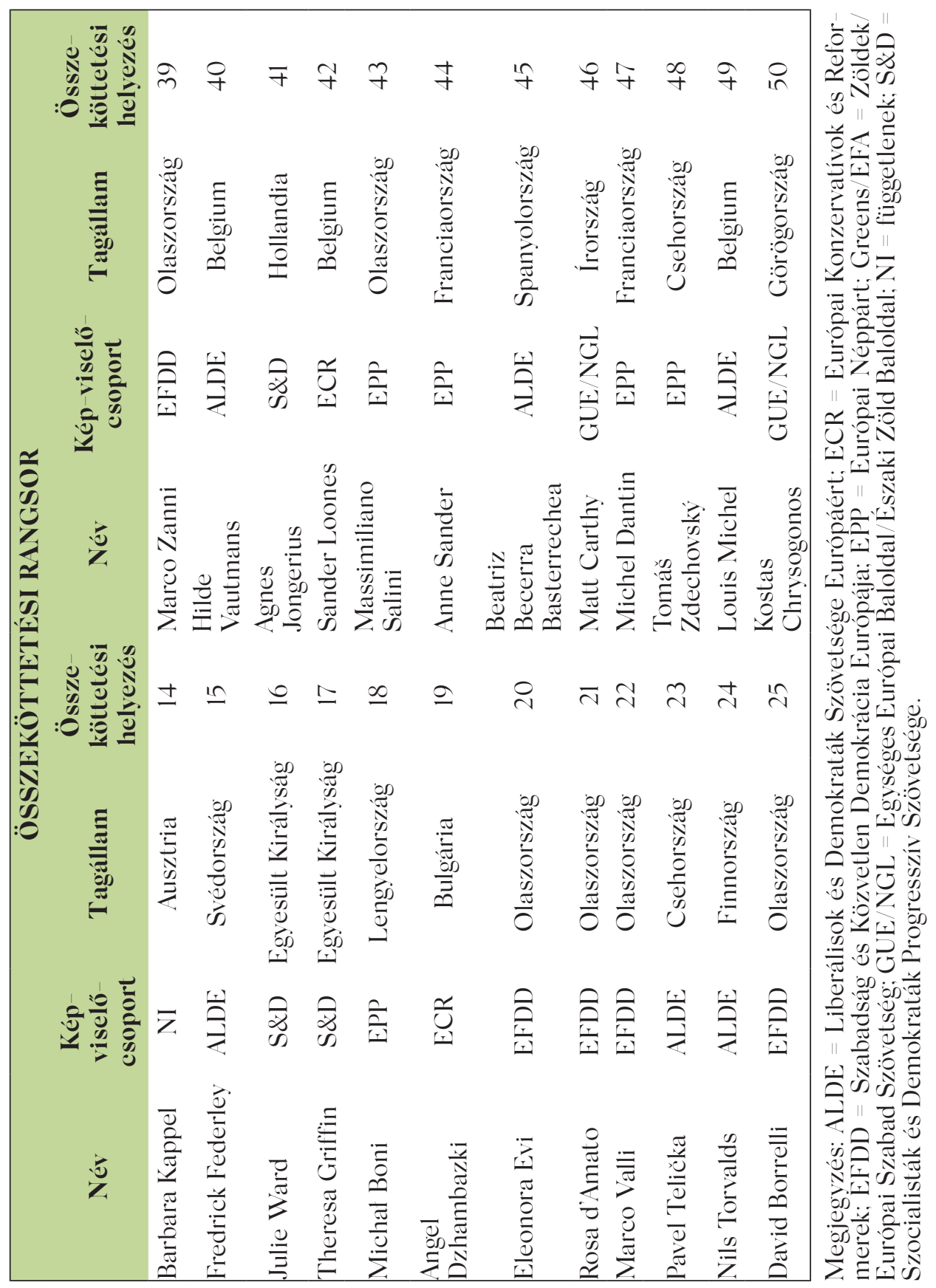

